Игорь Иванович КАЛИГАНОВ 


\section{СЕРБСКИЙ ИСТОРИОГРАФ И ПОЭТ ЙОВАН РАИЧ ${ }^{1}$}

\section{Аннотация:}

В статье рассказывается о жизни и творчестве видного деятеля южнославянского Национального возрождения, историографа, поэта и переводчика Йована Раича (1726-1801) - одного из самых образованных сербов своей эпохи. Он учился во многих странах, владел пятью иностранными языками, оставил после себя солидное оригинальное и переводное творческое наследие. Наиболее значительным среди него был объемный историографический труд «История разных славянских народов, наипаче Болгар, Хорватов и Сербов..., изданный в конце XVIII столетия в Вене и Санкт-Петербурге и заслуживший награды от австрийской и российской императриц. Не менее ярким был вклад Раича и в развитие национальной сербской поэзии. В отличие от историографических сочинений, которые Раич писал на русско-церковно-славянском языке, в своих стихах он использовал язык, близкий к живому сербскому разговорному.

\section{Ключевые слова:}

Национальное возрождение у южных славян, историография, сербский писатель из Воеводины, «История разных словенских народов, наипаче болгар, хорватов и сербов», религиозное и светское просветительство.

\section{Abstract: I.I. Kaliganov "The Serbian historiographer and POET, Jovan Raich".}

The article talks about the life and work of a prominent figure of the South Slavic national revival, historiographer, poet and translator Jovan Raich (serb. Jovan Rajič, 1726-1801), one of the most educated Serbs of his era. He studied in many countries, spoke five foreign languages, left behind a solid original and translated creative heritage. The most significant of his writings was the voluminous historiographical work "History of different Slavic peoples, primerely of Bulgarians, Croats and Serbs...", published at the end of the 18th century in Vienna and St. Petersburg and earned awards from the Austrian and Russian Empresses. Equally striking was Raich's contribution to the development of national Serbian poetry. Unlike the historiographical writings that Raich wrote in Russian-Church-Slavic, he used a language close to the living Serbian spoken language in his poems.

\section{Keywords:}

South Slavic national revival, historiography, Serbian writer from Vojvodina, "History of different Slavic peoples, primerely of Bulgarians, Croats and Serbs...", religious and secular enlightenment.

\section{$\breve{\nearrow}$} ован Раич (1726-1801) - выдающийся деятель Южнославянского национального возрождения, широко известный в православном славянском мире сербский писатель, поэт, переводчик, историограф, автор знаменитой «Истории разных словенских народов, наипаче болгар,

\footnotetext{
1 Работа выполнена при финансовой поддержке РФФИ (грант № 18-512-76004).
} 
хорватов и сербов», богослов. Он родился в небогатой семье в Сремских Карловцах в Воеводине - сербском городе, отошедшем Австрии после войны с Османской империей в 1688-1689 гг. и ставшем религиозным центром православных австрийских сербов. Именно здесь находилась резиденция митрополита и впоследствии были открыты первая сербская гимназия (1791) и семинария (1794). Азы знания Йован получил в школе у дьякона П. Райковича и Латино-славянской школе Рождества Богородицы, где преподавал выходец из России Эммануил Козачинский, а затем с 1774 г. еще 9 лет проучился в иезуитской гимназии Комарома и протестантском лицее Шопрона. За годы учебы он освоил латинский, церковнославянский, русский, немецкий и венгерский языки. Желая и дальше повышать уровня своего образования, Раич пешком отправился в Россию, где учился в Киево-Могилянской академии с 1753 по 1756 г.

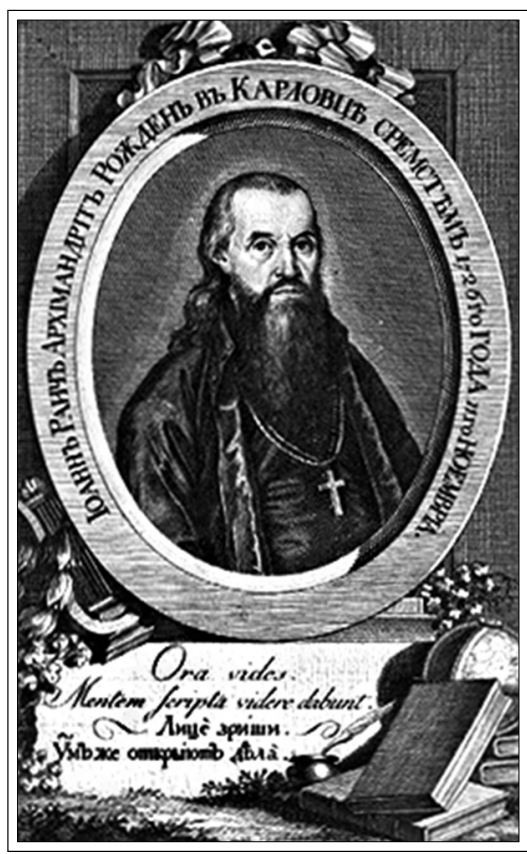

Иоанн Раич.

Гравюра 1794 г.

После окончания этого учебного заведения Раич активно путешествовал, побывал в Москве, Смоленске, Польше, Молдавии, Валахии, Константинополе и на Афоне. Затем он отдался педагогической работе: с 1759 по 1762 г. был преподавателем географии и риторики, а затем и ректором школы Покрова Богородицы в Сремских Карловцах. Через некоторое время по приглашению епископа Бачки Моисея Путника он прибыл в Нови Сад, где в течение 5 лет в качестве профессора преподавал теологию в Духовной академии (коллегиуме) и одновременно являлся ее ректором. В этот период и позднее он занимался переводами с церковнославянского и немецкого языков. Болышинство его переводных работ были на духовно-религиозную тему и принадлежали таким украинским и русским авторам, как Феофан Прокопович, Петр Могила, митрополит Платон (Левшин) и Лазарь Баранович. Можно отметить и перевод Раичем светской драмы «Урош V» («трагедија цара Уроша»), которую написал его учитель Э. Козачинский.

Последний период жизни Раича был связан с монастырской жизнью: в 1772 г. он принял монашеский постриг в расположенном в селе Ковиле близ Нови-Сада древнем монастыре святых Архангелов, который основал св. Савва Сербский. Затем он довольно быстро был рукоположен в иеромонахи, а потом поставлен в архимандриты и стал окормлять упомянутую обитель до конца своих дней. В этот период он написал первую историю сербской церкви и издал «Катехизис малый». 
Свою педагогическую и переводческую деятельность Раич сочетал с работой над реализацией своего замысла по написанию истории славянских народов, который возник у него значительно раньше. Во время своих путешествий Раич настойчиво занимался сбором необходимых ему для этого материалов. Очень плодотворным для него оказалось пребывание на Афоне и работа в Хилендарском монастыре, где он не только обнаружил множество полезных для себя документов, но и, видимо, встречался с деятелем Болгарского национального возрождения Паисием Хилендарским, который впоследствии написал свою эпохальную «Историю славяноболгарскую».

В 1768 г. Раич, по его словам, завершил свой исторический труд о славянах, но продолжал дорабатывать его свыше четверти века. Полное название сочинения звучало как «История разных славянских народов наипаче Болгар, Хорватов и Сербов от тьмы забвения изъятая и во свет исторический произведенная Іоанном Раичем архимандритом в свято-Архангелском монастире Ковиле». Этот его самый объемный труд впервые был опубликован в Вене двумя выпусками: книги 1-3 в 1794 г., а книга 4 - в 1795 г. Первая из них была вводной, а вторая посвящалась истории болгар и охватывала исторический период от истоков до конца XIV в., т.е. до завоевания Второго Болгарского царства турками, а также краткой истории хорватов. Остальные книги заключали в себе подробное изложение истории сербов и Сербии до Белградского мира 1739 г. и упразднения турками Печской патриархии.

Работая над этим сочинением, Раич сумел освободиться от многих средневековых принципов рассмотрения исторических источников и приблизиться к научной методологии нового времени. Он разделил свой труд на книги, главы и параграфы, снабдил его родословными древами правивших династий, хронологическими таблицами, картами и многими другими вспомогательными материалами и вплотную подошел к методике критического анализа исторических источников. Однако зачастую его выводы диктова-

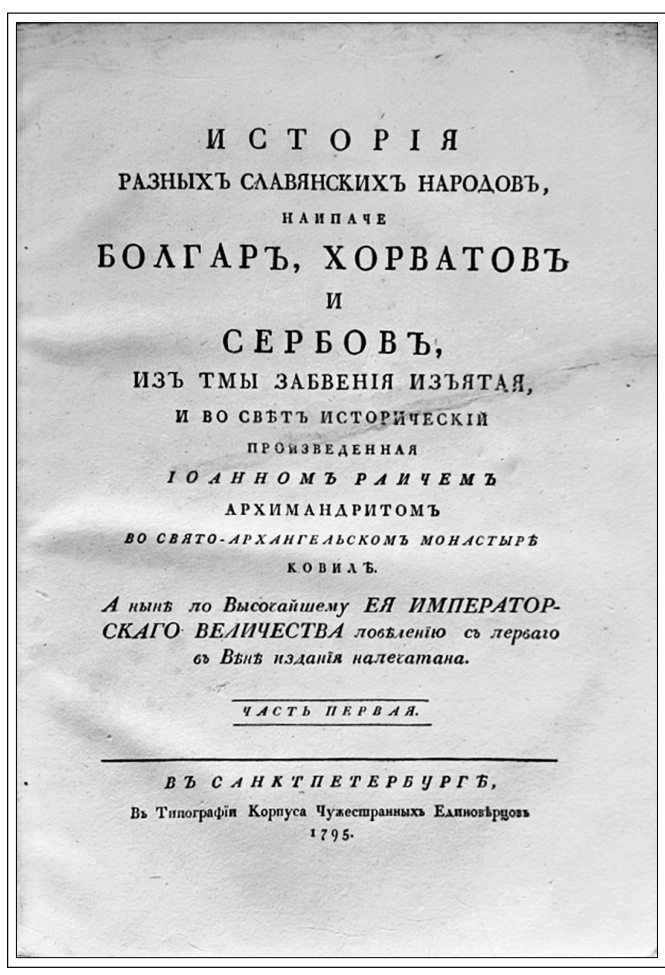

«История разных словенских народов» И. Рачча.

СПБ., 1795 г. 
лись патриотическими чувствами или конфессиональными (православными) пристрастиями, а отдельные части его труда имеют компилятивный, или предвзято просербский характер.

Несомненной заслугой автора явилось ведение в научный оборот сербских исторических источников. Новаторским для сербов явился и отказ Раича от прежних представлений о линейности и неизменности исторического времени - автор делит его на античную, средневековую и современную эпохи. Основными манифестациями «Истории...» Раича стали идеи единения порабощенных южных славян, культ просвещения и науки «столпа и украшения державы», чувство гордости за славянское историческое прошлое. Эта книга оказала большое воздействие на пробуждение национального самосознания южных славян и развитие у них исторической мысли. Для сербов она оставалась настольной книгой и основным научным источником по национальной истории вплоть до 60-х гг. ХІХ в.

Не меньшее значение она имела и для болгар, где аналогичное по своей идеологической направленности сочинение «История славяноболгарская» Паисия Хилендарского с 1762 г. распространялось в стране средневековым рукописным способом: первые отрывки из нее появились в печатном виде лишь в 1844 г. А вот в России упомянутое произведение Раича по понятным причинам было издано почти сразу же после Венского издания. Первый его выпуск был опубликован в Санкт-Петербурге в 1795 г. и вызвал среди русских читателей большой интерес. И это было немудрено, поскольку в нем он обнаруживал много ярких страниц, рассказывающих о завоевании балканских земель славянами и болгарами и создании там мощного средневекового государства, о легендах и исторических повествованиях, связанных с крещением Болгарии и «золотым» веком болгарского царя Симеона, о попадании болгар под византийское владычество, возрождении болгарской государственности, о приходе на Балканы турок в конце XIV в. и падении Болгарского царства. При этом Раич проявил себя отличным рассказчиком, который умеет заинтересовать читателя живостью повествования и способен взглянуть на одно и то же событие глазами многих историков, взвесив степень достоверности их мнений и верность выбора углов зрения. К сожалению, по цензурным соображениям издание второй части «Истории» Раича в России осуществлено не было. Целиком во второй раз труд знаменитого сербского историографа вышел в Будиме (Буде) в 1823 г.

Не менее значимым был вклад Раича и в развитие сербской национальной поэзии в жанре духовных стихов, эпитафии и исторической поэмы. Их он начал писать с 1790-х годов («Различные стихи» / «Pjesni različnija». Вес̌, 1790). Наиболее яркий след в истории сербской литературы оставила его историко-аллегорическая поэма «Бой змея с орлами» («Boj zmaja sa orlovi, Beč, 1791), созданная в Вене в разгар австро-русско-турецкой войны 1788-1790 гг. и посвященная историческому важному событию - временному освобождению Белграда. В отличие от «Истории...», написанной 
поэтом на русско-церковно-славянском языке, в поэме он обратился к сербскому народному языку. В ней заметно влияние барочной традиции киевской литературной школы. Реальные картины в поэме переплетаются с мифологическими и аллегорическими образами: «Змей» олицетворяет Османскую империю, а «Орлы» - Россию и Австрию. Торжественный тон по отношению к победителям соседствует с насмешливо юмористическим по отношению к врагу. Скрытым планом присутствует в поэме и «третья» сила - порабощенные сербы, которые, примкнув к союзным армиям, сражаются за свою свободу. Обозначившиеся в произведении Раича патриотичность, гражданственность, близость к народным чаяниям стали основными ориентирами для последующего развития сербской поэзии.

Заслуги Раича в развитии сербской культуры и национального духовного просвещения Екатерина II отметила золотой медалью со своим собственным изображением, а австрийская императрица Мария Терезия драгоценным архимандритским крестом. Не забыты они и в наше время: имя Йована Раича широко известно не только в Сербии, но и за рубежом.

\section{ЛИТЕРАТУРА}

Јован Рајић - живот и дело. Београд, 1997.

Йован Рајић - историчар, песник и црквени великодостојник. Зборник радова. Нови Сад, 2002.

Эрчич В. О поэме Йована Раича «Бой змея с орлами» // Русско-сербские литературные связи XVIII - XIX в. М., 1989.

Калиганов ИИ. Древние болгары в «Истории разных славянских народов» Йована Раича // Роль России в распространении знаний о славянстве. М., 2019. C.182-223.

\section{СПИСОК ИЛЛЮСТРАЦИЙ}

1. Иоанн Раич. Архимандрит. Гравюра из Санкт-Петербургского издания «Истории разных славянских народов». 1795 г.

2. Иоанн Раич. Гравюра ХІХ в. Государственный исторический музей. $P \Phi$.

3. Киево-Могилянская академия (1659-1817).

4. Афонский Хиландарский монастырь.

5. Титульная страница труда «История разных славянских народов». Санкт-Петербург. 1795 г.

6. Монастырь Свв. Архангелов в Ковиле близ Нови-Сада, где был пострижен, подвизался и упокоился Иоанн Раич.

7. Оглавление II Книги «О народе болгарском» в «Истории разных славянских народов» Иоанна Раича.

8. Большая золотая медаль с изображением лика Екатерины II награда И. Раича за его заслуги. 